Милош М. Ковачевић

Филолошки факултет

Универзитета у Београду
821.163.41.09:81'38

https://doi.org/10.18485/filkult.2016.2.ch1

\title{
ЈЕЗИК КЊИЖЕВНОСТИ ИЗМЕЪУ СРПСКЕ ФИЛОЛОГИЈЕ И СТИЛИСТИКЕ
}

\section{Сажетак}

У раду се анализира међуоднос језика књижевности као језика књижевних дјела и књижевног као стандардног језика, на примјеру српскога језика. Показује се какву је улогу имао језик књижевности у различитим фазама стандардизације српскога књижевног језика, а какву има данас. Посебна пажња у раду се посвећује анализи мјеста и карактеристика књижевноумјетничког стила у књижевном (стандардном) језику. Централни дио рада посвећен је освјетљењу (међу)односа: књижевни језик стандардни језик - језик књижевности, кроз приказ историјата датога питања и његове савремене интерпретације.

Кључне ријечи: српски језик, књижевни/стандардни језик, језик књижевности, књижевноумјетнички стил, стилема, стилска пререгистрација, интегрална стилистика

Оодносукњижевногјезика каонормираног, полифункционалног и еластично стабилног идиома којим се у свим сферама језичког општења користи једна друштвена заједница и језика књижевности као језика поетских и прозних умјетничких дјела - не само да је писано доста него и врло несагласно, неријетко толико несагласно да се поједина мишљења готово потпуно искључују. Два су супротстављена становишта-по једном: књижевни језики језик књижевности заправо су синоними јер значе исто, по другом: језик књижевности у ствари и не припада књижевном у статусу стандардног језика. Између тих супротстављених становишта налази се већи број “помиритељских" теорија, од којих највише присталица без сумње има она по којој језик књижевности представља само једну од сфера употребе књижевног 
језика - његов посебан, књижевноумјетнички, функционални стил.

При говору о међуодносу књижевног језика и језика књижевности нужно је укључити два аспекта - општетеоријски, који подаразумијева апстраховање свих поједничних језика, и корпуснотеоријски, који подразумијева свођење анализе тог међуодноса на случај некога појединачног језика. У овам нашем раду у питању је овај други, “корпусно-теоријски", приступ, јер је предмет анализе случај српског књижевног језика, и то као лингвистичког а не као политичког језика, тј. као језика који обједињује све његове политичке преименице: српскохрватски, хрватски, босански/бошњачки и црногорски (о односу српског језика и његових преименица в. опширно Ковачевић 2007, 2015б). При том, анализу међуодноса српског књижевног језика и језика на њему створене књижевности темељимо на двјестогодишњем периоду његовог постојања: од Вука Стеф. Караџића као његовог инаугуратора и реформатора, па самим тим и “творца", до данашњих дана.

\section{Народни језик у књижевности као књижевни језик}

Разматрање међуодноса српског књижевног језика и језика српске књижевности нужно је започети ставовима Вука Стеф. Караџића током читавог периода његове борбе за превођење српског народног у српски књижевни језик. А суштина тог "превођења" заправо се сводила на борбу за увођење народног језика у књижевност. Од самога почетка Вукове борбе за српски народни као књижевни језик његова се борба прије свега огледала у борби за увођење народног језика у књижевност. Тако се Вукове критике романа Милована Видаковића Усамљени јуноша (1814) и љубомир у Јелисијуму (1817) готово искључиво своде на критике Видаковићевог језика. «Вукова критика језика у књижевним делима» - рећи ће Драгиша Живковић - «своди се искључиво на питање граматичке правилности у језику. У његовим језичким критикама књижевног дела треба, дакле, гледати само један вид његове борбе за увођење народног језика и у лепу књижевност, и у науку, и у журналистику, и у политику, једном речи - у целокупан наш идејни живот» (према: Николић 
1968:331). Анализа Вукових ставова о језику српских књижевника, посебно о језику романа Милована Видаковића, показује да је «Вук мислио да наша нова књижевност, која тек почиње, мора имати и свој нови, народни језик. Доиста, младе књижевности, формирајући се, немају могућности да праве разлику између књижевног и народног језика, већ као књижевни морају увести баш народни језик» (Николић 1968:341). Улогу књижевног језика тако је Вук намијенио «народном језику у књижевности», из чега происходи да је прави српски књижевни језик народни језик употријебљен у књижевности, чиме се у ствари језик књижевности и књижевни језик поистовјећују. А да су се тог принципа Вук и његови сљедбеници досљедно придржавали, најбољу потврду пружа текст «Бечког књижевног договора» (1850), чија прва реченица гласи: «Доље потписани знајући да један народ треба једну књижевност да има, и по том са жалости гледајући, како нам је књижевност раскомадана, не само по буквици, него још и по језику и по правопису, састали смо се овијех дана, да се разговоримо, како бисмо се, што се за сад више може у књижевности сложили и ујединили» (Караџић 2014:65). Потписници, договарајући се око једног и јединственог језика, не кажу да «један народ треба један језик да има», него експлицитно наводе да «један народ треба једну књижевност да има», што заправо значи да је та књижевност једна по томе што је писана једним језиком. Тако «Књижевни договор" једнозначно показује да су и Вук и сапотписници сматрали да нема разлике између језика књижевности и књижевног језика, тј. да се управо, ако не и једино, у језику књижевности и очитује прави књижевни језик. ${ }^{1}$

Све до средине XX вијека, а заправо до почетка његове седме деценије, узорним књижевним језиком сматран је језик књижевности. Тако ће А. Белић педесетих година XX вијека написати: "Наш књижевни језик-народни је језик употребљен у књижевности" (Белић 1952:6). Белић сматра да се стилска слобода књижевницима

1 То потврђује и биљешка којом у Народним новинама Људевит Гај пропраћује објављивање текста “Књижевног договора", у којој он “Књижевни договор" ишчитава као договор о нужности једног јединственог језика: "Predpolagajući, da namiera niže slavljenoga nama iz Beča poslanog dogovora i š njim skopčanih pravilah nije druga, već da se uvede jednakost u načinu pisanja medju našima spisateljima, priobćujemo ga domorodnomu čitateljstvu na razsudjenje" (Караџић 2014:65). 
једино може допустити у окриљу књижевног језика. Свако одступање у језику књижевности од норми књижевног језика, по Белићу, не само да је граматичка него је и стилистичка погрешка. "Ја сам рекао" - вели Белић - "да и наш књижевни језик, као и сви други на свету, има своје законе и своја правила; али да језичка правилност његова нимало не смета слободноме стварању књижевника, исто онако као што тонови скала, који су за све музичаре исти, нису ни најмање спутавали генијалне полете великих музичких талената. Сваки ће добар писац, пуштајући наш књижевни језик кроза се, дати му знаке свога стваралаштва, обогатити га у неком правцу. Он ће развијати његову унутрашњу и спољашњу лепоту, додајући му нове преливе у значењу и стварајући по готовим угледима - који су у њему самом као живи материјал и жива снага - нове речи за нове појмове. Њему није потребно да, тога ради, унакази, насилно поремети или повреди што у њему. Тако се ни у каквој уметности не постижу успеси од трајне вредности!" (Белић 1951:132). Непоштовање норми књижевног језика у језику књижевности Белић ће сматрати кварењем језика. “Било да књижевник не влада језиком "- ријечи су Белићеве - "било да неће о њему да води бриге, већ га својој ћуди подвлашћује, - он за нас подједнако квари језик. Књижевни језик који иде свесном кварењу језика за нас је једнако несвесном кварењу. Насиље над језиком и незнање језика за нас су синоними. Ако писац хоће навлаш да је нејасан, тајанствен и магловит, то може учинити и без насиља над језиком; за то му је довољно насиље над смислом. Да ли ће такво дело и даље остати књижевно дело од вредности, то је друго питање; али језик мора бити и у њему исправан" (Белић 1951: 125-126). Језик књижевности за Белића, дакле, мора бити књижевни језик, при чему је језик књижевности његов најузорнији и најзначајнији дио. Са Белићем је у погледу престижног статуса језика књижевности у књижевном језику потпуно сагласан Људевит Јонке, што најексплицитније потврђује његова крилатица “Пиши онако како добри писци пишу!" Та крилатица XX вијека треба да у историју смјести Вуков(ск)у крилатицу XIX вијека: “Пиши онако како народ говори!" Јер, “писати данас" - вели Јонке - “онако како народ говори, схваћено дословно, значило би враћати се у прошлост, лишавати се драгоцјених обогаћења књижевног језика, полазити у фолклор, па и 
у дијалект. Јер данашњи се наш књижевни језик не поклапа више у цјелини ни сједним народним говором. Стога се пред сваког данашњег писца поставља као нужан задатак упознавање норме савременога књижевног језика, онога језика којим пишу најбољи књижевници, онога језика који се уздигао изнад дијалекта и постао наш заједнички језички израз” (Јонке 1964:16). Језику писаца, према томе, “језична је правилност conditio sine qua non, а умјетнички елемент је оно што се тражи и што треба да буде присутно и откривено" (Јонке 1964:15). Иако језик писаца сматра најузорнијим, престижним књижевним језиком, Љ. Јонке ипак књижевни језик опсегом не изједначава са језиком књижевности. Књижевни језик, рећи ће Јонке, "то није дакле само језик књижевности, него језик читаве народне културе: и споразумијевања, и рада, односно пословности, и књижевности, и науке, и поезије, дакле свега онога у чему се изражава култура једног народа" (Јонке 1964:13).

Људевит Јонке не само да се може сматрати бранитељем модификоване теорије о нерезликовности (подударности) језика књижевности и књижевног језика, него и заступником теорије о друкчијем статусу језика књижевности у књижевном језику. Јонке је, наиме, први експлицитно у сербокроатистици изашао с идејом да језик књижевности јесте и мора бити књижевни језик, али да књижевни језик није и не мора бити језик књижевности. Друкчије речено, Људевит Јонке је - и то најприје у раду “О разноликој служби књижевнога језика” 1952. године - “први пут код нас указао на значај стилске диференцијације језика” (Стојановић 2002: 91), показујући "како су разнолике и особите функције књижевнога језика и како свакој треба да приступимо с гледишта њезиних особитости” (Јонке 1952:104). Јонке наглашава да је “особито разграната и важна функција пјесничкога језика или, како га још и другачије зовемо, језика умјетничког дјела. У овој функцији језик је постао материја, од које се гради умјетничко дјело. Само се по себи разумије, да је за ову функцију језика најпретежнија управо естетска оцјена" (Јонке 1952:103). Уз то ће Јонке, позивајући се на Тимофејева, потцртати да “језик лијепе књижевности одражава језик друштва у свој његовој сложености и у узајамној вези свих његових различитих области, док су све друге форме употребе језика тако рећи једностране, т.j. 
употребљавају оне облике језика, који су својствени само одређеној области" (Јонке 1952:103-104). Овим је својим радом Јонке одшкринуо поље истраживања функционалностилске раслојености књижевног језика, дајући језику књижевности у оквиру књижевног језика статус само једног од функционалних стилова. Друкчије речено, језик књижевности није више синоним књижевном језику, него је само један његов, истина најбитнији, дио.

Десетак година након Јонкеове инаугурације сербокроатистичке функционалне стилистике, у којој је језик књижевности изгубио статус синонима књижевном језика, Милка Ивић ће у двама својим радовима довести у питање не само престижну улогу “језика књижевника" унормативном (књижевном) језику, него иоправданост употребе самога термина "књижевни језик".

\section{Књижевни или стандардни језик}

“Што се тиче језичке данашњице”, - вели Милка Ивић - “она мора бити представљана оним што је најмање специфично, а највише просечно, стандардна. Зато се овде не смемо ослонити искључиво на језик књижевника, јер он не може (и не сме) илустровати безбојност просека. Књижевници су језички новатори по вокацији. За књижевнике, уосталом, није никаква тајна да и сама тематика о којој се саопштава по себи намеће одређени језички избор. Штавише, они намерно, да би нам што верније дочарали животну стварност у својим делима, уплићу у своје дијалоге и градски супстандард и дијалекат", тако да ће “просечност језичке свакидашњице биће најприкладније илустрована, у ствари, оним што је најмасовније усвојено као инструмент комуникације: језик штампе, радија, телевизије, филма" (Ивић 1990 [1965] : 95, 96). Пошто је “језику књижевности” укинула статус репрезентативног корпуса за актуелни нормирани језик, М.

2 1) Данашњи аспекти проучавања српскохрватског књижевног језика, зборник за филологију и лингвистику, IV-V, Нови Сад, 1961-1962, 110-116; 2) Проблем норме у књижевном језику, Књижевност и језик, XII/3, Београд, 1965, 13-20; Jezik, Zagreb, 1965, XIII/1, 1-8. Оба рада прештампана су у књизи М. Ивић (1990), према којој и дајемо цитате из тих радова. 
Ивић ће оспорити и традиционални назив тог нормативног језика. "Пре свих разговора о модерном српскохрватском књижевном језику" - пише Милка Ивић - "требало би рашчистити појмове око тога шта је то уопште к њ и же в н и ј е з и к. У много случајева долази до изражаја један неспоразум, изазван непрецизношћу термина књижевни. Због сазвучја са речју књижевност (исп. однос међу оригиналним латинским терминима litterarius-litteratura) уобичајено је у нашој средини да се под појмом књижевни језик подразумева само језик лепе књижевности. Заборавља се да се 'књижевно', тј. по кодексу нормативне граматике, изражава сваки образован човек, да нам, поред лепе књижевности, 'књижевно' говоре и штампа, и радио, и научна публикација, и канцеларијски акт, и уџбеници по школама... У ствари, језик лепе књижевности јесте само један специфичан тип оне језичке стварности кроз коју долази до изражаја наша савремена култура. Можда бисмо и ми добро учинили да могућност неспоразума о коме је реч потпуно уклонимо тиме што ћемо увести нов термин, нешто што би одговарало пољском 'polszczyna kulturalna', енглеском 'standard language' или немачком 'Schriftsprache'.

Језик лепе књижевности је уизвесном смислуи ужи и ширипојам од језика културе. Ужи, зато што представља само једну специфичну реализацију језика културе; шири, зато што обухвата индивидуална стилска остварења која се иначе не појављују у стандардној језичкој норми" (Ивић 1990 [1961-1962]:87).

Иницијативу М. Ивић о потреби замјене "неадекватног" а традиционалног термина "књижевни језик" неким адекватнијим и модернијим придружиће се и - без позивања на М. Ивић као "иницијатора" - детаљно образложити њену основаност Далибор Брозовић осам година касније $(1970)^{3}$ у књизи која већ у наслову има тај нови, код М. Ивић већ предложени, модерни ангицистички термин стандардни језик. Предност термина "стандардни језик" Д. Брозовић ће покушати доказати сучељавањем његових терминолошких карактеристика са карактеристикама термина "књижевни језик". "У терминолошким суставима појединих језика" - вели Брозовић “влада велико шаренило конкурената термину 'стандардни језик'.

3 А заправо пет година касније, јер је ријеч о тексту први пут штампаном 1967, и прештампаном без измјена у књизи Брозовић (1970). 
Најважнији међу њима јест литера(ту)рни језик, руски literaturnyj jazyk, њем. Literatursprache, енгл. literary language, франц. langue litteraire, тал. lingua letteraria, хрватскосрпски књижевни језик. Тај термин има само једну добру особину: дугу традицију и широку усвојеност. Асоцијативно је лош због премалене дистанцираности према ужем, специјализираном термину језик литературе. С истога је разлога уопће незгодно укључити ријеч литература или књижевност у двочлани термински назив за стандардни језик - у књижевности се не употребљава само стандардни језик и зато је термин литера(my) рни језик преширок: литература (тј. белетристика) служи се и разним другим органским и неорганским идиомима вишега и нижега ранга, најчешће у дијалогу, али не само у дијалогу, нпр. нестандардним писменим језицима као што је провансалски, дијалектима и интердијалектима језика који имају свој стандардни вид као хрватскосрпски или га немају као кашупски, затим разним видовима разговорнога језика, жаргонима и сл. С друге стране, термин литера(mу)рни језик уједно је и преузак, јер је очито да се стандардни језик не употребљава сам о у белетристици. Но преко тих аргумената могли бисмо с обзиром на усвојеност и традицију ипак пријећи да не постоји и принципијелан разлог за напуштање термина литера(ту)рни језик. Тај термин асоцира и предоџбе о доминатној улози белетристике у стандардном језику као појави, предоџбе које су одраз разних идеалистичких концепција и које су опасно оптерећење на путу к сувременијим и прогресивнијим схваћањима стандардног језика. Наравно, постоји и опасност да се потцијени важност белетристике, опасност која се јавила као реакција на застарјеле концепције, али у тај проблем не бих желио овдје улазити - битно је да је литература само једна од компонената о којима се води рачуна у стандардном језику, несумњиво најважнија компонента, особито у раним фазама стандардних језика, али принципијелно само prima inter pares" (Брозовић 1970: 15-16).

Већину Брозовићевих аргументи за "стандардни језик" поменула је и М. Ивић у изношењу мана “књижевног језика", прије свега његову сазвучну асоцијативну везу са "језиком књижевности" и његово “прешироко" и “преуско" значење. Брозовић чак напомиње да би се преко тих “мана” и могло прећи да није “принципијелног 
разлога" за напуштање термина књижевни/литерарни језик, а он се огледа у томе што “тај термин асоцира и предоџбе о доминатној улози белетристике у стандардном језику као појави", која је, међутим, "само једна од компонената о којима се води рачуна у стандардном језику, несумњиво најважнија компонента”, али принципијелно само прва међу једнакима. А тај принципијелни разлог управо негира статус језика књижевности у српском и/или српскохрватском књижевном језику у његовом стогодишњем развоју. Насупрот Брозовићу, међутим, Б. Хавранек, један од најзначајнијих теоретичара и твораца теорије књижевног језика, наведени Брозовићев "принципијелни разлог" сматра врло битним аргументом не против, него у корист термина “књижевни језик". По Хавранеку је, наиме, једно од иманентних својстава књижевног језика "садржано у самом термину 'књижевни језик' у многим језицима (француски la langue littéraire, руски литературный язык итд.) тј. ради се о језику књижевности, прије свега лијепе књижевности. Ова улога заступљена је већ у богатој љествици главних функција књижевног језика, али ја хоћу да ову улогу посебно истакнем. Зашто? 3бог тога што у лијепој књижевности језик има не само улогу (задатак) изражавања и информисања, него је он и стваралачки чинилац, компонента умјетничке структуре и грађа књижевнога дјела" (Хавранек 1977: 9). Осим тога, и Д. Брозовић и М. Ивић као да заборављају да термини не “болују" од асоцијативности и значењске мотивисаности, јер им се значење одређује дефиницијом. По истој би логици онда било нужно замијенити термин "замјеница", који у свим језицима асоцира на значење замјењивања, а општепознато је да замјенице нису замјењивачке него упућивачке (деиктичке) ријечи. Никоме, међутим, не пада на памет да укида термин замјеница, управо због “дуге традиције и широке усвојености", што су карактеристике и термина "књижевни језик". Треба се, међутим, упитати како то да се у већим језицима и значајнијим лингвистикама, какав је нпр. руски језик и русистика, не поставља питање оправданости употребе термина "књижевни језик". А Брозовић ће итри и по деценије касније као главни аргумент против термина “књижевни језик" поновити то што он “има несумњиву везу с појмом књижевности ('сестринске струке'). Каже се додуше" наставља Брозовић - "да треба разликовати појаве 'књижевни језик' 
и 'језик књижевности'. Но то је двоструко неодрживо - с једне стране овако или онако остаје веза с појмом књижевности, а она није толико битна за појам стандарднога језика", па зато сматра "да је назив стандардни језик за појам традиционално зван 'књижевни језик' из много разних разлога бољи од назива књижевни језик. Једнозначан је, што је веома важно у називословљу сваке струке, и без алузије на битност књижевне компоненте за тај појам" (Брозовић 2005:187). Оба Брозовићева аргумента - и асоцијативниост на "језик књижевности" и алузивност "на битност књижевне компоненте" - готово потпуно ће, хвалећи Брозовићев допринос (!), обезвриједити Р. Катичић, сљедећом тврдњом: “Књижевни језик наш је традиционални назив. Он нема везе с умјетности ријечи, него је то језик какав се раби у књигама. Добро би се могао звати и 'писмени језик', као што се на њемачком зове Schriftsprache и на француском langue écrite. Назван је по томе што је језик писмености. [...] Стандардни језик, без обзира на то што му назив зрцали друкчији менталитет и изражава гледање из друге перспективе, ипак није друго него књижевни језик, који, и кад се потпуно стандардизира, остаје то што је и био. Нимало му се не кидају везе с књижевношћу, која такођер остаје то што је била и кад се почне стварати на стандардном језику. Стандардни језик тако насљеђује сав књижевни језик из којега се развио као своју изражајну могућност" (Катичић 2009: 51). Потребу за термином “стандардни језик" Катичић оправдава чињеницом да је "стандардни језик увијек књижевни језик, у сваком значењу и смислу који тај назив носи. Но није сваки књижевни језик и стандардни. Стога стандардни језик није исто што и књижевни и за њ треба посебан назив. Стандардни је језик одређен и уређен до највише мјере која је за њ достижна" (Катичић 2009: 51-52), друкчије речено, “стандардни језик је највиши развојни ступањ књижевнога" (Катичић 2009: 50).

О односу "књижевног" и "стандардног језика" много се више расправљало у хрватској неголи у српској филологији, иако је, како смо видјели, ту дискусију иницирала М. Ивић. Треба, међутим, напоменути да М. Ивић није једина од српских лингвиста која је настојала да термину “књижевни језик" укине статус "стандарднога језика". Подршку је добила и од П. Ивића, који, за разлику од М. Ивић, неће бити тако искључив о неподобности термина "књижевни 
језик", нити о учитавању његовог погрешног значења, него ће о његовом саодносу са термином "стандардни језик” рећи: “Термин књижевни језик је заиста бољи него стандардни језик ако они значе исто. Невоља је у томе што њихово значење није увек сасвим једнако. Књижевни језик је пре свега језик књижевности и није сасвим јасно у којој мери он обухвата нпр. стручну терминологију Ако је стандардизована, она свакако спада у стандардни језик, али да ли се називи делова локомотиве или хемијских једињења могу убројати у књижевни језик. [...] С друге стране, у књижевности има много тога што не припада језичком стандарду. Многи писци данас употребљавају елементе сленга или дијалектизма у својим делима. Због свега тога раширена је употреба поменутих двају термина као делимично синонимичних: њихова значењска поља се укрштају. То су два круга који имају велику заједничку површину, али изван ње остају на обе стране подручја која покрива само један или други од тих термина. Разуме се, у таквом случају оба термина би имала места у терминолошкем систему" (Ивић 2014 [1983]: 92), с тим да “о стандардном језику не треба говорити док се књижевни језик није заиста стандардизовао, тј. - док није постао стандардни језик" (Ивић 2014: 146).

Терминолошкој збрци око значења термина "књижевни језик" чини се да је у србистици највише кумовао управо П. Ивић. Он ће, наиме, у својој Дијалектологији, први пут објављеној 1956. године, (не)свјесно мијешати значења термина “књижевни (стандардни) језик" и “језик књижевности". Тако у Ивићевој Дијалектологији на једном мјесту читамо како је "шумадијско-војвођански дијалекат послужио, од почетка 18. в. наовамо, као подлога новом српском књижевном језику који се формирао прво на територији Угарске (претежно у данашњој Војводини) а затим и у северној Србији", а на другом мјесту како се "крајем XV и почетком XVI в. формирао у Дубровнику књижевни језик на бази месног јекавског говора” (Ивић 2001 [1956]: 92, 195). У оба случаја, међутим, није ријеч о књижевном језику, него само о језику књижевности.

Усрпскоме језику, у исвим његовим политичким преименицама, врло су ријетки случајеви у којима се термин "књижевни језик" употребљава(о) за именовање “језика књижевности”, тако да 
инсистирање противника овога термина на таквом значењу заправо и нема чвршћег емпиријског упоришта, што за посљедицу има чињеницу да је и даље у србистици (као и у кроатистици, боснистици, монтенегринистици) термин “књижевни језик" неупоредиво фреквентнији у употреби од термина "стандардни језик". При том се у оквиру књижевног језика као посебан функционални стил увијек издваја и "књижевноумјетнички", чији је предмет истраживања искључиво “језик књижевности”.

\section{Језик књижевности - функционални стил или “надстил”}

Тачно тридесет година након напријед поменутог Јонкеовог пионирског текста о значају фунцкионалностилских изучавања књижевног језика, појавиће се "прво опсежније истраживање на подручју функционалне стилистике српског језика", које је "спровела Стаменка М. Радић (1982) под руководством А. Менац. Пионирска дисертација одбрањена на

Филозофском факултету Свеучилишта у Загребу посвећена је контрастивном проучавању општих лексичко-граматичких карактеристика српске и руске научно-техничке литературе" (Стојановић 2002: 92). А “највећи допринос на плану популаризације стилистике код нас даје књига Функционални стилови Б. Тошовића (1988). Та књига је - посебно за домаће србисте (и не само за њих) постала,датакокажемо,букварфункционалнестилистике" (Стојановић 2002:94). Тошовићева је књига највише допринијела појачаном интересовању за функционалностилска, како чисто србистичка и/или сербокроатситичка тако и контрастивна истраживања, а прије свега иницирала потребупотпунијегописа функционалнихстилова српскога и/или српскохрватског језика. Након те Тошовићеве књиге, која ће се 2002. појавити и у проширеном издању (Тошовић 2002), различитим аспектима анализе функционалних стилова српскога језика биће посвећен велики број радова, али и двије монографске књиге, једна на хрватском а друга на српском језичком простору (Симић, Јовановић 2002. и Силић 2006), као и двије општестилистичке монографије, с укљученим поглављима о функционалним стиловима (Вуковић 2000. 
и Катнић-Бакаршић 2001). У датим књигама, као и у свим радовима који се баве класификационим питањима функционалних стилова, неизоставно се као један од стилова књижевног језика издваја и књижевноумјетнички, као стил чији је предмет анализе прозни и поетски језик књижевности.

Ниједном функционалном стилу у србистици и/или сербокроатистци није посвећено толико пажње колико књижевноумјетничком. Од средине XX вијека, откад се књижевно дјело почиње посматрати и интерпретирати као језичко књижевно дјело, велики број хрватских и српских књижевних критичара и лингвиста, при чему је број књижевних критичара и теоретичара неупоредиво већи, почиње се темељније и теоријски и емпиријски бавити стилистиком књижевног текста. Тај стилистички приступ књижевном тексту могао би се одредити као стилемско-стилистички, односно микростилистички, као приступ у коме доминира анализа стилема као минималних стилистичких јединица, и то и са њихове стилематичне и са њихове стилогене стране, при чему су се лингвисти у анализама исцрпљивали углавном само на истраживању стилематичности (а стилематичност се своди на истраживање формалног или семантичког онеобичајења језичке јединице), а књижевни истраживачи само на стилогености (при чему стилогеност подразумијева истраживање функционалне вриједности језичке јединице, што ће рећи њене естетске или умјетничке вриједности). У основи такав приступ језику књижевности био је доминантан од средине педесетих до почетка осамдесетих година XX вијека у вријеме дјеловања тзв. Загребачке стилистичке школе, која је окупљала хрватске књижевне теоретичаре и лингвисте око часописа Умјетност ријечи (о “микростилистици" Умјетности ријечи врло обавјештајно пише Јосић 2011)4. "Утемељитељи Школе били су Зденко Шкреб, Александар Флакер и Иво Франгеш, а настављачи њихова рада Станко Ласић, Мирослав Бекер, Виктор Жмегач, Миливој Солар, Радослав Катичић, Крунослав Прањић, Гајо Пелеш и други. Свим је језичним и књижевним теоретичарима окупљенима у Загребачкој стилистичкој школи билозаједничко и за све карактеристично што сувише илимање

4 За историјат лингвостилистичке идеје значајан је и радљ. Јосић (2016), који је посвећен “доприносу часописа Језик (1962-1971) конституирању хрватске лингвостилистике". 
полазили од језика и језику придавали велику позорност схваћајући га као полазиште и средиште тумачења књижевнога дјела. Били су заокупљени стилистичком проблематиком, прије свега пријепором треба ли тумачити језик књижевних дјела у оквиру лингвистичке или литерарне стилистике (Ј. Силић). Колико је то релевантан и сложен проблем, види се по томе што је актуалан још и данас (К. Багић), више од 40 година послије првих полемика о томе. Представници Школе примјењивали су тзв. иманентни приступ књижевному дјелу, што значи да су га проматрали као аутономну појаву" (Удиер 2011). И након осамдесетих година, у Хрватској већи број истраживача наставља традицију бављења језиком књижевности, између којих се, како то приказу њихових резултата потврђује С. Л. Удијер (2011), својим радовима истичу: Мирко Пети, Иво Прањковић, Јосип Силић, Крешимир Багић, Марина Ковачевић и Лада Бадурина.

Тема језика књижевног дјела није заобишла ни српске истраживаче. Врло вриједне и оригиналне стилистичке доприносе, и то у окриљу микростилистике књижевног текста, дају прије свега Д. Живковић и Н. Петковић, без сумње два најзначајнија српска књижевна стилистичара друге половине XX вијека (о стилистичким, прије свега лингвостилистичким доприносима Живковићевим и Петковићевим говори исцрпно Ковачевић 2009, 2011а, 2015а). Од српских лингвиста лингвостилостиком се у већем броју радова и књига баве М. Ковачевић, М. Чаркић и А. Милановић. М. Чаркић се првенствено бави лингвостилистиком стиха, унутар које доминира питање стилистике риме (Чаркић 1995, 2016. и 2013), А. Милановић (2010) најчешће стилеметичношћу лексема у језику српских пјесника, док М. Ковачевић у својим стилистичким радовима и књигама (Ковачевић 2015 [ $\left.{ }^{1} 1991,{ }^{2} 1995,{ }^{3} 2000\right], 2011,2012,2013,2015$ в, 2015г) тежи стварању теорије интегралне стилистике, примјењујући њене критеријуме на велики број прозних и поетских текстова српских писаца. Интегрална стилистика се при том одређује као стилистика која “уједињује и а) лингвостилистику, која се у првом реду бави стилематичношћу, тј. начинима структурисања стилема као формално и/или семантички онеобичајених јединица, и б) књижевну стилистику, која се бави стилогеношћу, тј. књижевним ефектом, који изазивају како стилематичне тако и нестилематичне језичке јединице. 
Интегрална стилистика бави се, значи, стилематичношћу стилема и стилогеношћу и стилема и нестилема. Предмет интегралне стилистике јесте истраживање начина остваривања (међу)односа стилематичности и стилогености језичких јединица: од фонеме као најмање до дискурса или текста као највише. Ако је стилематичност стилистичка форма језичке јединице, тј. формални отклон који дату јединицу супротставља уобичајеној, онда је стилогеност умјетнички ефекат или умјетничка вриједност неке језичке јединице. Из тога происходи да језичке јединице, посматране са стилематично-стилогеног аспекта, могу бити четвороврсне: а) само стилематичне (када је јединица формално онеобичајена, али та формална онеобичајеност не производи умјетнички ефекат), б) само стилогене (када је у питању општеупотребна језичка јединица, јединица стандардне језичке структуре, али умјетнички функционална, тј. са изразитом умјетничком вриједношћу), в) и стилематичне и стилогене (када језичка јединица има и онеобичајену форму и умјетнички вриједност), и г) и нестилематичне и нестилогене (када језичка јединица нема онеобичајену форму, а уз то и не производи књижевни ефекат). На тај начин интегрална стилистика у поље свог истраживања укључује све јединице које чине структуру књижевног текста, без обзира јесу ли оне само стилематичне, само стилогене, или пак и стилематичне и стилогене, односно и нестилематичне и нестилогене. Интегрална стилистика, поновимо, изучава оба плана језичких јединица у књижевном тексту - и стилематични и стилогени - уједињујући на тај начин лингвистичку са књижевном стилистиком. Уколико тог уједињења не би било, и једна и друга анализа, и лингвистичка и књижевна, заправо би биле 'крње', теоријски чак тешко 'одбрањиве' - јер је свака анализа структуре језичких јединица у књижевном тексту испразна, несврсисходна ако се у обзир не узима њихова умјетничка функција, односно свака је анализа умјетничке функцију језичких јединица незамислива ако се у обзир не узму њихове структурне карактеристике» (Ковачевић 2015г: 45-46).

Интегрална стилистика тако превладава «камен спотицања» о томе коме приоритетно припада подручје истраживања језика писаца, на што експлицитно указује Л. Худечек (2006) у оцјени прегледа хрватских радова о језику писаца - «да готово нема хрватског језикословца 
који се није у којој фази својег рада заинтересирао за језик хрватских писаца. Већ сам тај податак показује актуалност ове теме, а показује то и расправа о односу језика књижевности и хрватског језика која се, каткад жешће, каткад смиреније, готово непрекидно води између двају 'табора': литерарних стилиста и језикословаца» 5 .

Треба ли уопште напомињати да су стилематичност и стилогеност као аксиолошки критеријуми, посебно још кад се посматрају у суодносу, искључива карактеристика језика књижевности, односно књижевноумјетничкогстила, и то врлодоминантна а истовремено према другим функционалним стиловима дистинктивна карактеристика. Зато се стилематично-стилогене особине јављају најсуштаственијим особинама микростилистичког приступа књижевном тексту, односно језику књижевности.

Језик књижевности се, међутим, и на макростилистичком, што ће рећи на плану књижевноумјетничког стила као цјелине, такође од свих других функционалних стилова разликује по једној врло значајној, само њему иманентној особини - по поступку пререгистрације. Термин пререгистрација (енг. reregistration) први пут су 1990. године употријебили Р. Картер и В. Неш (1990), с тим да се “под пререгистрацијом подразумијева могућност преузимања било којег регистра [=функционалног стила] у књижевноумјетничком тексту, при чему књижевни текст, као самодовољан, може генерирати значења и ситуације, заправо, виртуелни свијет, путем језика. С једне стране, такав поступак ствара додатни ниво значења књижевноумјетничког текста, док с друге стране преузети елементи у новом окружењу попримају нове карактеристике, односно нови семантички и стилистички потенцијал" (Катнић - Бакаршић 2001: 107-108).

Тако се књижевноумјетнички стил од осталих функционалних стилова диференцира и на микро и на макростилистичком плану, и то на микро плану стилематско-стилогеним вриједношћу језичких јединица, а на макро плану поступком пререгистрације, као стилске “интеграције" нелитерарних текстова у литерарне. Зар је онда чудо

5 Уп. и: “У раздобљу Загребачке стилистичке школе, које је трајало од средине педесетих до краја седамдесетих или почетка осамдесетих година прошлога стољећа, раздобљу у којему је покренут часопис за књижевност знаковита назива Умјетност ријечи, готово да и није било језикословца који се није зауставио на језику књижевности те се њиме позабавио" (Удиер 2011). 
да је од најстаријих времена језик књижевности супротстављан осталим типовима језика, и што је између функционалних стилова књижевноумјетнички, као по много чему уникатан, “искакао" из функционалностилских класификационих критеријума.

Најстарије експлицитно промовисање језика књижевности у посебну врсту језика везано је за разликовање поетског језика и језика поезије. А по истраживањима Р. Мајенове, први пут ће, у Италији, Ђанбатиста Вико у свом знаменитом дјелу Scienza nuova (1725) диференцирати појмове “језик поезије" и “поетски језик" (Мајенова 2009:50). Први термин, “језик поезије”, генетички је ранији и "стоји на становишту које не допушта да се у дефиницију поезије унесе посебан тип језика. Знаци поетског текста не подлежу суштинским унутрашњим трансформацијама у односу на текстове непоетских језика". Други термин пак "посматра поетски језик као посебан тип језика, као битну одредницу поезије. Знаци језика у тој функцији подлежу значајним унутрашњим трансформацијама у односу на знаке других типова језичких текстова" (Мајенова 2009: 49). Од Вика па до данас готово да нема ниједнога истраживача који не сматра да је поетски језик посебан тип језика-јасним критеријумима диференциран од непоетских типова језика.

А од свих типова језика, поетски је језик, сматра Ј. Мукаржовски, најближи књижевном језику. Та се веза често објашњава “у смислу да је песнички језик једна од варијаната књижевног језика, руковођена општом законитошћу ове више формације. Тако њихов узајаман однос схватају нарочито пуристи, који чисте књижевни језик од туђих елемената, то јест не само од туђих већ и од домаћих али некњижевних, оних који се противе књижевном језику. Али, ако покушају да на овај начин дисциплинују и песнички језик, показаће се како у њиховим очима велики део уметничких поступака изгледа као самовољно кршење језичке 'чистоте', управо због тога што песништво не познаје ограничење на само једну одређену област језичких средстава. [...] Разлика између песничког и књижевног језика, значи, сасвим је очигледна. Али, таква разлика не шкоди њиховој блиској повезаности, која се састоји у томе што књижевни језик и у раздобљима у којима песништво најрадикалније крши његову норму, представља позадину на којој се језичка страна 
песничког дела прима. Управо се одступања од књижевног узуса у песничком језику вреднују као уметнички поступци. То не важи ни за један други слој језика (функционалан, друштвени или други), па ни за онај из којег песништво у датом тренутку обилно узима; тако, на пример, и песме писане у целини у аргоу или у дијалекту, уколико се доживљавају као саставни део 'вештачког' песништва, имају за позадину књижевни језик, иако радикално крше његову норму. Са гледишта песничког језика, његова блискост са књижевним језиком манифестује се кроз утицај који песништво врши на развој књижевне норме. Наравно, овај утицај није такав да би све оно што песништво у језичком погледу створи одмах и аутоматски прелазило у књижевну норму" (Мукаржовски 1986: 53).

Због тога језик књижевности и/или поетски језик и јесте интегрални дио књижевног језика ${ }^{6}$, његова посебна манифестација, посебан функционални стил. Али тај је "стил радикално различит у односу на све друге. Та различитост, наравно, није таквог степена да се може говорити о сасвим другом језику, иако је у историји овог проблема било и таквих мишљења. Може се рећи да постоји само један језик, али да он у књижевном стварању доживљава велике трансформације. Његово суштинско својство, које га у том смислу издваја, јесте једно специфично запостављање комуникативности, у стандардном значењу тог појма, односно 'посувраћање' комуникативности на сам израз и затварање у неку врсту круга" (Вуковић 2000:118-119).

А да се "историја понавља", показује и случај оживљавања тезе о језику књижевности као језику неподводивом ни под књижевни језик, ни под његове функционалне стилове, с тим да се "оживљавање" давнашњих идеја о “посебном језику" не врши прибављањем нових критеријума старој тези, него се представља као нови поглед на статус језика књижевности. Тако К. Багић (1997) у студији “Белетристички стил" покушава, не без иронијског подтекста, оповргнути два увријежена става о језику књижевности: 1) «Пиши онако како добри

6 А зар то најбоље не потврђује чињеница да је у корпусу рјечника савременог књижевног језика (нпр. Речника српскохрватскога књижевног језика, Нови Сад: Матица српска, 1967-1976) корпус књижевних дјела, нормално претежније прозних него пјесничких, више него двотрећински. 
писци пишу!», и 2) «Белетристички стил један од функционалних стилова књижевног (стандардног) језика», наводећи против сваког од тих ставова по пет негирајућих разлога («аргумената»). Тако се, по Багићу, први став, чију је крилатицу «лансирао» Љ. Јонке (1964:15-16), никако не може прихватити, зато 1) што «поистовећује језик литературе и језик комуникације», 2) што се не можемо сложити «који су то добри писци «, 3) што се критеријално не може одредити корпус добрих писаца (будући да се морамо угледати на «писање више њих»), 4) што не може бити «ријеч о добром писцу» ако је «језик фикционалних текстова узорит образац за стандардни језик» (пошто писац у «градњи књижевног фантразма креира приватну граматику и приватни правопис, говори посредно, фигуративно, не смјерајући притом бити језично коректан»), и 5) «што и писци сами, када пишу нефикционалне текстове, пишу друкчијим дискурзом него када пишу фикционалне текстове» (Багић 1997). Колико је Багићево «аргументовање» на климавим ногама, види се и по томе што он потпуно игнорише «завјештање» творца теорије књижевног језика Б. Хавранека да «ми не можемо лик данашњег књижевног језика који себи стварамо или његову дефиницију, која важи за савременост, - директно преносити на минула раздобља» (Хавранек 1977: 10). Осим тога, Багић интенционално и «селективно» чита и тумачи Љ. Јонкеа, на што је у литератури већ указано (Вуковић 2007; Јосић 2010:41; Мићановић 2011), јер није логично да Јонке, који, како смо већ видјели, први у сербокроатистици пише о функционалностилском раслојавању књижевног (стандардног) језика, тај језик своди само на језик књижевности; уосталом, Јонке и у тексту који Багић критикује више него експлицитно негира Багићево «читање», напријед већ цитираном тврдњом да књижевни језик - «то није дакле само језик књижевности, него језик читаве народне културе».

Ни са аргументима којима негира став о "белетристичком стилу" као посебном функционалном стилу стандардног језика Багић није био много боље среће. У негацији датога става Багић експлицитно наводи пет аргумената, од којих су четири експлицитна, а пети, који не наводимо, параболичан: “1) Функционални стилови су друштвено верифицирани устаљени начини исказивања, а белетристички стил је схематска апстракција изведена из начелних одлика разнородних и 
аутономних литерарних исказа; 2) Функционални стилови производ су стварних човјекових потреба за практичним облицима комуникације, док литерарне исказе одликује управо супротно: посредан однос према стварности односно непостојање стварнога контекста и без остатка појашњиве човјекове потребе за литерарним исказом; 3) Док функционални стилови готово изравно раде против језичне креативности, белетристички стил обједињује исказе које управо одликује језични ексклузивизам. Будући да белетристички текст нема референта у стварности, то јест будући да га његов аутор сам креира, језик у литератури има свјетотворну улогу, или - лотмановски речено - језик литературе је у односу на природни језик моделацијски сустав другог ступња; он је један од језика на којима нам култура говори; и 4) Семантика израза или исказа у типичним функционалним стиловима је такођер функционална - устаљена и прозирна, док је семантика белетристичких текстова обично неразрјешива. Сваки белетристички текст има онолико потенцијалних смислова колико је његових потенцијалних читача односно читања". На основу датих негирајућих аргумената Багић сматра да “белетристички стил није један од функционалних стилова који би 'испуњавао' једну од функција језика. У односу на функционалне стилове могло би га се одредити као надстил, јер увјетно користи или може користити све потенцијале које језични сустав посједује или допушта; он се не обликује унутар сустава као један од његових подсустава него - симболички речено - полифункционалност представља као своју функцију" (Багић 1977). Слиједећи Багића, С. Л. Удиер ће, на Багићев(ск)им критеријумима, након обимне анализе односа језика књижевности према другим функционалнимстиловима, закључитидасе“захваљујућитим бројним специфицностима, као и својој аутономности у односу на стандардни језик, језик књижевности треба сматрати језиком sui generis те се не треба проматрати и проучавати као дио стандарднога језика и као дио сустава функционалних стилова, већ само у своме специфичну односу с опћим језичним суставом и структуром књижевнога дјела којега је дио" (Удиер 2010: 19). К. Багић и С.Л. Удиер слажу се, дакле, у томе да језик књижевности није функционални стил књижевног језика, него је он за Багића “надстил”, а за С.Л. Удиер “језик sui generis". Пропитујући врло критеријално аргументе што су их понудили 
Багић и Удиер, Љ. Јосић ће у опширном раду карактеристична наслова "Књижевноумјетнички стил - функција стандардног језика, језик sui generis или “надстил'?” јасно образложити слабе стране датих тумачења. Тако ће она, након исцрпне анализе аргумената "за и против књижевноумјетничког стила", закључити да "све већи број теоретичара заступа тезу да се књижевноумјетнички стил не може (барем не изравно) доводити у однос према стандарду и његовим нормама. Међутим, чињеница је да се управо с помоћу проучавања односа књижевноумјетничкога стила према нормама стандарда продубљивало наше схваћање језика као медија књижевности и језичних избора који, стваралачком снагом аутора, имагинацијом и креацијом, истодобно надмашују норме стандарда колико их у једноме својем дијелу слободним одабиром потврђују. Ваља закључити и да апорија функционалностилистичке раздјелбе не одражава само властитост књижевноумјетничкога стила због које се проблематизира његова припадност језику као стандарду, већ она одражава и повијесни развој стандарднога језика који се увелике разликује од сувременога језичног стања. Довољно је подсјетити се колику су важност у повијести хрватскога језичног стандарда имали књижевници друге половине XVIII. стољећа и колики опсег у цјелокупној грађи на темељу које су настајали нормативни језични приручници и лексикографска дјела обухваћа књижевноумјетнички стил" (Јосић 2010: 45-46). И заиста, погледа ли се корпус рјечника савременог језика, лако је уочљиво да њега више него двотрећински чине текстови језика књижевности. Па како онда језик књижевности искључити из књижевног (стандардног) језика!? Зато све наведене и навођене самосвојне карактеристике језика књижевности треба сматрати диференцијалним цртама према другим “језицима”, или према другим функционалним стиловима, будући да је српски књижевни језик (под којим се подразумијевају и сва његова политичка преименовања) заправо прије свега кодификовани језик лијепе књижевности.

У односу на комуникативни језик и на њему засноване функционалне стилове, језик књижевности разликује се прије свега “степеном моделативности". Наиме, језик књижевности, за разлику од природног, комуникативног језика, има статус "другостепеног 
моделативног система". “Оне системе у чијој је основи” - вели Ј. М. Лотман - "природни језик и који прихватају допунске надструктуре, стварајући језике другога степена, прикладно је назвати другостепеним моделативним системима" (Лотман 1991:541). Основна карактеристика тих другостепених система огледа се у томе што “при прекодирању уметничког система на неуметнички језик увек остаје 'непреведени' остатак - она над-информација, која је могућна само у уметничком тексту" (Лотман 1991:550), односно што су у књижевности као другостепеном систему, а посебно у поетском језику, “сваки детаљ и текст у целини укључени у различите системе односа, добијајући на крају више значења. Пошто је откривено у метафори, то својство има општи карактер" (Лотман 1991:549). Управо из тих разлога готово се као самоочигледно истинит потврђује став К. Мићановића "да данас белетристички текстови могу служити као моделски текстови, али ако притом 'моделске текстове' (Амон) разумијевамо прије свега као оне текстове у којима се поштује стандарднојезична норма. То значи да аутори белетристичких текстова својом писаном праксом овјеравају, тј. само потврђују постојеће стандарднојезичне норме, постојећа кодификаторска рјешења, и у том се смислу такви белетристички текстови сматрају моделским текстовима. У мањој мјери белетристички текстови могу служити и као моделски текстови у смислу да ауторима кодификаторских приручника служе као извор кодификације из којих црпу своја кодификаторска рјешења" (Мићановић 2011). А то посредно значи да се језик књижевности својим највећим дијелом потврђује као књижевни језик, тако да је тешко изамислити књижевни језик без језика књижевности. Темељну потврду књижевном језику даје језик књижевности, док "другостепена моделативност" језика књижевности, управо својом “другостепеношћу", упућује на немогућност свога постојања без комуникативног или природног језика као “првостепеног система". "Унутар стилистике често су" вели М. Катнић Бакаршић - “постојале дилеме и подјеле око тога да ли књижевност, тј. литерарни дискурс, може и треба бити предмет проучавања стилистике. Можда је управо на тој разини стилистика као раскрижје неријетко била мјесто растанка и подјеле, а не сусрета. У неким правцима само се књижевност, односно књижевноумјетнички 
стил, сматрао или још увијек сматра предметом стилистике. У другим школама сматрало се пак да стилистика треба проучавати све друге стилове, док књижевност треба оставити књижевној критици и теорији. [...] Парадоксално, сама та комплементарна подјела показује међусобну овисност књижевног и некњижевних дискурса. Тешко да би било могуће проучавати стил драмскога дијалога без познавања дијалога у разговорном стилу и обрнуто. Проучавање стила књижевнога текста или стила некога књижевника данас често подразумијева лингвистички приступ (на Западу је ту доминантна Халидејева системско-функционална лингвистика), као и теорију интертекстуалности, наратологију, теорију стилских и наративних фигура, постколонијалну критику и низ других модела, а избор одређених приступа и модела увијек зависи од конкретнога текста или групе текстова" (Катнић Бакаршић 2015).

\section{Литература}

Багић 1997: Krešimir Bagić, Beletristički stil - pokušaj određenja, Kolo, br. 2, Zagreb, 1997, 5-16. <(http://stilistika.org/stiloteka/rasprave/114-beletristicki-stil> (приступ: 22. 5. 2016)

Белић 1951: А[лександар] Белић, Око нашег књижевног језика: Чланци, огледи и популарна предавања, Београд: Српска књижевна задруга, 1951.

Белић 1952: Александар Белић, О уједначавању у језику, Наш језик, н. с. IV /1-2, Београд, 1952, 1-8.

Брозовић 1970: Dalibor Brozović, Standardni jezik. Teorija, usporedbe, geneza, povijest, suvremena zbilja, Zagreb: Matica hrvatska, 1970.

Брозовић 2005: Dalibor Brozović, O početku hrvatskoga jezičnog standarda, Jezik, god. 52, br. 5, Zagreb, 2005, 186-192.

Вуковић 2000: Novo Vuković, Putevi stilističke ideje, Podgorica - Nikšić: Jasen, 2000.

Вуковић 2007: Petar Vuković, U pozadini načela "Piši kao što dobri pisci pišu", Jezik, god. 54, br. 3, Zagreb, 2007, 109-118.

Ивић 1990: Милка Ивић, О језику Вуковом и вуковском, Нови Сад: Књижевна заједница Новог Сада, 1990.

Ивић 2001: Павле Ивић, Дијалектологија српскохрватског језика, Сремски Карловци, Нови Сад: Издавачка књижарница Зорана Стојановића, 2001.

Ивић 2014: Павле Ивић, Полемички и други сродни списи, књ. 1, Сремски Карловци, Нови Сад: Издавачка књижарница Зорана Стојановића, 2014.

Јонке 1952: Ljudevit Jonke, O raznolikoj službi književnog jezika, Jezik, god. 1, br. 4, Zagreb, 1952, 100-105. 
Јонке 1964: Ljudevit Jonke, Književni jezik u teoriji i praksi, Zagreb: Nakladni zavod Znanje, 1964.

Јосић 2010: Ljubica Josić, Književnoumjetnički stil - funkcija standardnoga jezika, jezik sui generis ili "nadstil"?, Studia lexicographica, god. 4, br. 2, Zagreb, 2010, 27-48.

Jocић 2011: Ljubica Josić, Mikrostilistika Umjetnosti riječi: jezikoslovna razradba koncepta stilema, Studia lexicographica, god. 5, br. 2, Zagreb, 2011, 85-102.

Jocuћ 2016: Ljubica Josić, Kolektivno $i$ individualno u stilu: Doprinos priloga časopisa Jezik (1962-1971) konstituiranju hrvatske lingvostilistike < http://stilistika.org/josic> (pristup: 22. 5. 2016)

Караџић 1968: Вук Стеф. Караџић, О језику и књижевности I, Београд: Просвета, Сабрана дела Вука Караџића, књига 12, 1968.

Караџић 1986: Вук Стеф. Караџић, О језику и књижевности II, Београд: Просвета, Сабрана дела Вука Караџића, књига 13, 1986.

Караџић 2014: Вук Стеф. Караџић, О језику и књижевности III/2, Београд: Вукова задужбина, Просвета, Сабрана дела Вука Караџића, књига 14, 2014.

Катичић 2009: Radoslav Katičić, O standardnom i književnom jeziku, Jezik, god 56, br. 2, Zagreb, 2009, 50-53.

Катнић-Бакаршић 2001: Marina Katnić-Bakaršić, Stilistika, Sarajevo: Ljiljan, 2001.

Катнић Бакаршић 2015: Marina Katnić Bakaršić, Stilistika na raskrižju - kojim putem dalje?, u: Svijet stila, stanje stilistike, urednica Anera Ryznar, Zagreb: Filozofski fakuletet u Zagrebu, 2015. < http://stilistika.org/svijet-stila-stanja-stilistike> (pristup: 22.5.2016)

Картер, Неш 1990: Ronald Carter and Walter Nash, Seeing Through Language, Oxford: Blackwell, 1990.

Ковачевић 2003: Милош Ковачевић, Белићеви погледи на стилистику, у: Граматичке и стилистичке теме, Бања Лука: Књижевна задруга, 2003, 197-219.

Ковачевић 2007: Милош Ковачевић, Однос српског и српскохрватског књижевног језика, у: Српски језик, књижевност и уметност, књ. 1: Српски језик и друштвена кретања, уредник Радоје Симић, Крагујевац: ФИЛУМ, 2007, 5162.

Ковачевић 2009: Милош Ковачевић, О стилистичким погледима Новице Петковића, у: Споменица академику Новици Петковићу, уредио Рајко Петров Ного, Бања Лука: Академија наука и умјетности Републике Српске, 2009, 141-156.

Ковачевић 2011: Милош Ковачевић, Стилска значења и зрачења, Ниш: Филозофски факултет у Нишу, 2011.

Ковачевић 2011а: Милош Ковачевић, Лингвостилистика у књижевним анализама Новице Петковића, у: Језик, књижевност, култура: Новици Петковићу у спомен, зборник радова, уредили Јован Делић и Александар Јовановић, Београд: Институт за књижевност и уметност, Филолошки факултет Универзитета у Београду, 2011, 237- 253.

Ковачевић 2012: Милош Ковачевић, Лингвостилистика књижевног текста, Београд: СКЗ, 2012.

Ковачевић 2013: Милош Ковачевић, Српски писци у озрачју стилистике, Београд: 


\section{Филологија културе}

Филип Вишњић, Гацко: СКПД Просвјета, 2013.

Ковачевић 2015 [ $\left.{ }^{1} 1991,{ }^{2} 1995,{ }^{3} 2000\right]:$ Милош Ковачевић, Стилистика и граматика стилских фигура, IV битно допуњено издање, Београд: Јасен, 2015.

Ковачевић 2015а: Милош Ковачевић, Драгиша Живковић као лингвостилистичар, у: Књижевни теоретичар, стилистичар, историчар и компаратиста Драгиша Живковић, уредник Мило Ломпар, Београд: Филолошки факултет, 2015, 119-137.

Ковачевић 2015б: Милош Ковачевић, Српски језик измеђулингвистике и политике, Бања Лука: Друштво наставника српског језика и књижевности Републике Српске, 2015.

Ковачевић 2015в: Милош Ковачевић, Стил и језик српских писаца, Београд: Завод за уџбенике, 2015.

Ковачевић 2015г: Милош Ковачевић, Интегрална стилистика у настави српског језика, у: Настава и наука у времену и простору, уредници др Живорад Миленковић, др Снежана Башчаревић, Лепосавић: Учитељски факултет у Призерену-Лепосавић, 2015, 37-68.

Лотман 1991: Jurij Mihailovič Lotman, Teze ka problemu «Umetnost u nizu modelativnih sistema» , u: Teorijska misao o književnosti, priredio Petar Milosavljević, Novi Sad: Svetovi, 1991, 541-553.

Мајенова 2009: Marija Renata Majenova, Teorijska poetika: problemi jezika, prevod s poljskog Biserka Rajčić, Beograd: Službeni glasnik, 2009.

Милановић 2010: Александар Милановић, Језик српских песника, Београд: Завод за уџбенике, 2010.

Мићановић 2011: Krešimir Mićanović, Beletristika i standardni jezik, u: Vlast i kodifikacija, Universitetsko izdatelstvo «Paisij Hilendarski», Plovdiv, 2011, 157-165. <http:// stilistika.org/stiloteka/rasprave/107-beletristika-i-standardni-jezik> (pristup: 22. 5. 2016)

Мукаржовски 1986: Jan Mukaržovski, Struktura pesničkog jezika, prevod sa češkog Aleksandar llić, Beograd: Zavod za udžbenike i nastavna sredstva, 1986.

Николић 1968: Берислав Николић, Напомене и објашњења, у: Вук Стеф. Караџић, О језику и књижевности I, Београд: Просвета, Сабрана дела Вука Караџића, књига 12, 1968, 241-387.

Прањковић 2005: Ivo Pranjković, Jezik i beletristika, Zagreb: Disput, 2005.

Силић 2006: Josip Silić, Funkcionalni stilovi hrvatskoga jezika, Zagreb: Disput, 2006.

Симић, Јовановић 2002: Р. Симић, Ј. Јовановић, Основи теорије функционалних стилова, Београд: Јасен, 2002.

Стојановић 2002: Андреј Стојановић, Функционална стилистика на српском језичком подручју, Стил, год. І, бр. 1, Београд, 2002, 79-103.

Тошовић 2002 [1988]: Бранко Тошовић, Функционални стилови, Београд: Београдска књига, 2002.

Удиер 2010: Sanda Lucija Udier, Jezik književnosti i sustav funkcionalnih stilova standardnoga jezika», Lahor, br. 9, Zagreb, 2010, 7-20.

Удиер 2011: Sanda Lucija Udier, Jezik književnosti u modernome hrvatskome jezikoslovlju 
i književnoj znanosti, Kolo, br. 5, Zagreb 2011. <http://www.matica.hr/kolo/318/ Jezik\%20knji\%C5\%BEevnosti\%20u\%20modernome\%20hrvatskome\%20jezikoslovlju\%20i\%20knji\%C5\%BEevnoj\%20znanosti/)> (pristup: 16. 12. 2014).

Хавранек 1977: Bohuslav Havranek, Teorija književnog jezika, Književni jezik, VI/1, Sarajevo, 1977, 7-16.

Худечек 2006: Lana Hudeček, Hrvatski jezik i jezik književnosti, u: Zbornik radova 34. seminara Zagrebačke slavističke škole, urednik Krešimir Bagić, Zagreb: Zagrebačka slavistička škola, 2006, 57-79. <http://www.academia.edu/3196026/Hrvatski_ jezik_i_jezik_knji\%C5\%BEevnosti > (pristup: 5. 8. 2015)

Чаркић 1995: Милосав Чаркић, Фоностилистика стиха, Београд: «Научна књига», Институт за српски језик САНУ, 1995.

Чаркић 2006: Милосав Чаркић, Стилистика стиха, Београд: Међународно удружење «Стил», Институт за српски језик САНУ, 2006.

Чаркић 2013: Милосав Чаркић, Стих и језик, Београд: Институт за српски језик CAHУ, 2013.

Milos M. Kovacevic

Faculty of Philology

University of Belgrade

\section{THE LANGUAGE OF LITERATURE BETWEEN SERBIAN PHILOLOGY AND STYLISTICS}

\section{Summary}

The paper analyzes the interrelation that exists between the language of literature as the language of literary works and the literary language as the standard language on the example of the Serbian language. It emphasizes the role that the language of literature had in different stages of the standardization of Serbian literary language, as well as the one that it has today. The paper pays special attention to the analysis of the place and characteristics of literary artistic style within literary (standard) language. The central part of the paper is dedicated to clarifying (inter)relations: literary language standard language - language of literature, through an overview of the history of issue itself and its modern interpretations.

Key words: Serbian language, literary/standard language, language of literature, literary artistic style, styleme, stylistic pre-registration, integral stylistics 